\title{
PENERAPAN STRATEGI PEMBELAJARAN CONTEXTUAL TEACHING AND LEARNING DALAM MENINGKATKAN KREATIVITAS BELAJAR SISWA PADA PEMBELAJARAN SAINS
}

\author{
Ekaristina Saragi dan Naeklan Simbolon \\ naeklan.simbolon@yahoo.com \\ Jurusan PGSD FIP Universitas Negeri Medan \\ Jalan Willem Iskandar Pasar V Medan, 20221
}

\begin{abstract}
The problem is the lack of creativity research students in science lessons in grade IV A SD N 106789 Tanjung Gusta Deli Serdang Academic Year 2011/2012. This study aims to improve students' learning creativity using the contextual teaching and learning.This study is a Class Action Research (CAR) conducted in two cycles, where each cycle conducted two meetings. So in the second cycle there $4 \mathrm{x}$ meeting. In each cycle will be carried out through four stages, namely planning, implementation, observation and reflection. Instrument made in this penelitisn is based on observations to measure the level of creativity of student learning.Based on the results obtained from 30 students can be seen that after each cycle of action on an increase creativity in learning. It can be concluded that through contextual learning strategies can improve student learning creativity in teaching science subjects Thermal Energy And Its use in Class IV A SD N 106789 Tanjung Gusta Deli Serdang.
\end{abstract}

Keywords: Contextual Learning Strategy, Creativity Learning Students

\section{PENDAHULUAN}

IPA (Sains) merupakan cara mencari tahu tentang alam secara sistematis untuk menguasai pengetahuan, fakta-fakta, konsepkonsep, prinsip-prinsip, proses penemuan, dan memiliki sikap ilmiah. Sains umumnya memiliki peran penting dalam peningkatan mutu pendidikan. Khususnya di dalam menghasilkan peserta didik yang berkualitas, yaitu manusia yang mampu berpikir kritis, kreatif, logis dan berinisiatif dalam menanggapi isu di masyarakat yang diakibatkan oleh dampak perkembangan sains dan teknologi.
Hal ini berarti untuk mempelajari sains diperlukan kemampuan atau kreativitas siswa agar dapat mempelajari sains dengan mudah.

Berdasarkan hasil observasi yang peneliti lakukan di kelas IVA SD Negeri 106789 Tanjung Gusta menunjukkan bahwa pembelajaran sains masih didominasi oleh penggunaan metode ceramah dan pemberian tugas yang kegiatannya lebih berpusat pada guru. Metode ceramah ini kurang merangsang siswa dalam berpikir dan bertindak kreatif untuk aktif terlibat secara langsung dalam pembelajaran sains. Selain itu, guru belum terampil 
dalam menggunakan variasi metode pembelajaran yang tepat.

Melalui pendekatan pembelajaran kontekstual belajar akan lebih bermakna karena anak "mengalami" apa yang dipelajarinya, bukan "mengetahuinya". Dalam konteks itu, siswa perlu mengerti apa makna belajar, apa manfaatnya, dalam status apa yang mereka pelajari berguna bagi hidupnya nanti. Dengan begitu memposisikan dirinya sendiri sebagai bekal yang akan diperlukannya untuk hidupnya nanti. Siswa mempelajari apa yang akan bermanfaat bagi dirinya dan berupaya menggapainya.

Hasil penelitian ini diharapkan dapat bermanfaat dalam menunjang pelaksanaan kurikulum Pendidikan di Sekolah Dasar. Selain itu, hasil penelitian ini diharapkan dapat memberikan kontribusi bagi kompetensi mengajar guru dan memberikan gambaran kondisi pembelajaran menggunakan strategi pembelajaran contextual teaching and learning atau pembelajaran kontekstual di kelas bagi para penentu kebijakan seperti kepala sekolah. Siswa dapat memahami materi pelajaran dan meningkatkan kreativitas belajar siswa pada mata pelajaran sains terutama pokok bahasan energi panas dan penggunaannya, sebagai bahan dan masukan untuk menambah wawasan bagi para peneliti lainnya.

\section{METODE PENELITIAN}

Penelitian ini merupakan penelitian tindakan kelas dengan menggunakan metode deskriptif kualitatif. Dalam penelitian tindakan kelas ini digunakan model
Spiral Kemmis dan Mc Taggart (1998) dengan prosedur penelitian yang terdiri atas perencanaantindakan, observasi, evaluasirefleksi yang bersifat daur ulang atau siklus.

Subjek yang dikenai tindakan dalam penelitian ini adalah siswa IVA SD Negeri 106789 Tanjung Gusta Kabupaten Deli Serdang Tuan TA. 2011/2012, yang berjumlah 30 orang siswa. Penelitian tindakan kelas ini dilakukan selama 3 bulan yang terdiri atas 2 siklus dengan prosedur penelitian masing-masing siklus terdiri atas: 1) rencana tindakan, 2) pelaksanaan tindakan, 3) observasi dan 4) refleksi.

Penulis menggunakan observasi yang mengacu pada indikator peningkatan kreativitas belajar siswa. Analisis data dilakukan dengan menggunakan prosedur dengan menerjemahkan jenis data dari hasil observasi menjadi data kualitatif dalam bentuk deskripsi tentang: a) langkah-langkah pembelajaran kontekstual dalam meningkatkan kreativitas belajar siswa dan b) menggunakan perhitungan perubahan yang terjadi pada siswa untuk mengetahui seberapa besar tingkat keberhasilan dari tindakan yang dilakukan. Untuk mengetahui sejauh mana perubahan yang dialami siswa dalam proses pembelajaran dengan menggunakan pembelajaran kontekstual yang dilaksanakan, peneliti juga menyediakan lembar pengamatan pelaksanakan pembelajaran.

Tingkat keberhasilan dari tindakan yang dilakukan dengan menggunakan kriteria sebagai berikut: skor $80-100 \%$ tingkat kreativitas belajar siswa tinggi; skor 
60-79\% tingkat kreativitas belajar siswa sedang; skor 0-59\% tingkat kreativitas belajar siswa rendah. Persentase skor siswa yang termotivasi adalah sebagai berikut: $65 \%-100 \%=$ kreatif dan $0 \%-64 \%=$ belum kreatif.

\section{HASIL DAN PEMBAHASAN}

Penelitian tindakan kelas ini dilakukan selama dua siklus. Pada tiap pentahapan siklus diupayakan dapat menghasilkan kegiatan pembelajaran yang efektif dan efisien. Berdasarkan hasil penelitian ini dapat dibuktikan bahwa pembelajaran kontekstual dapat meningkatkan kreativitas belajar siswa pada pelajaran sains di kelas IVA SD N 106789 Tanjung Gusta.

\section{Adapun}

pembelajaran

kontekstual yang dilakukan dalam penelitian ini tampak melalui langkah-langkah pembelajaran sebagai berikut: pada siklus I, pembelajaran dilakukan dengan langkah-langkah: peneliti memberikan penjelasan secara singkat tentang pengertian energi panas dan sumber energi panas terbesar yang ada di bumi, selanjutnya peneliti menjelaskan kegunaan energi panas yang ada di lingkungan sekitarnya. Kemudian peneliti memperagakan contoh adanya energi panas pada gesekan dua benda dengan menggosokgosokkan kedua tangan yang kemudian diikuti siswa dengan memperagakan contoh energi panas pada gesekan dua benda dengan menggosok-gosokkan kedua tangannya. Kegiatan meniru ini merupakan salah satu komponen dalam pembelajaran kontekstual yang dapat mengaitkan materi pelajaran dengan pengalaman langsung siswa.

Pertemuan kedua, peneliti terlebih dahulu membagi kelompok belajar siswa dalam 6 kelompok yang terdiri dari 4 dan 5 orang siswa, kemudian peneliti menjelaskan secara singkat bagaimana proses dari perpindahan panas secara radiasi terjadi. Peneliti juga berusaha membangun konsep pemikiran siswa tentang proses dari perpindahan panas secara radiasi yang dapat terjadi dalam kehidupan sehari - hari siswa. Untuk menguatkan pemahaman siswa, peneliti melakukan kegiatan modelling, yaitu percobaan 1 . Percobaan ini dilakukan agar siswa memperoleh pengalaman langsung bagaimana sesungguhnya perpindahan panas secara radiasi itu terjadi. Setelah peneliti memodelkan percobaan 1, selanjutnya peneliti menjelaskan langkah-langkah percobaan yang akan dikerjakan dan menginstruksikan siswa untuk melakukan percobaan 1 di dalam kelompok belajar. Selama siswa melaksanakan percobaan 1 , peneliti memantau dan membimbing siswa, setelah itu, peneliti merangsang siswa untuk menyampaikan hasil percobaan kelompok siswa masingmasing.

Pembelajaran pada siklus 2 dilakukan dengan langkah-langkah sebagai berikut: peneliti mengawali pembelajaran dengan menjelaskan sedikit materi tentang perpindahan panas secara konduksi, kemudian dilanjutkan dengan pembagian kelompok belajar dalam 6 kelompok yang terdiri dari 4 dan 5 orang siswa, selanjutnya peneliti membagikan alat-alat percobaan 
dan menjelaskan langkah-langkah percobaan yang akan dilakukan.

Pertemuan keempat, kegiatan yang dilaksanakan peneliti hampir sama dengan kegiatan sebelumnya, yang berbeda adalah pada pertemuan keempat peneliti membentuk 3 kelompok belajar dengan anggota yang berbeda dari kelompok sebelumnya

Hasil observasi siswa pada siklus I, pertemuan I: hanya 5 siswa yang memperoleh kriteria sangat baik; 9 siswa yang memperoleh kriteria baik; 5 siswa yang memperoleh kriteria cukup baik; 4 siswa yang memperoleh kriteria kurang; dan 7 siswa yang memperoleh kriteria kurang sekali.

Berdasarkan kreativitas seperti ditunjukkan pada Tabel 1, ada

14 siswa yang memiliki persentase kreativitas antara 65\% sampai $100 \%$ dan dapat dikatakan sudah kreatif karena telah memenuhi kriteria penilaian dari indikator kreativitas belajar. Berdasarkan rata-rata kelas dapat dikatakan bahwa tingkat kreativitas belajar siswa kelas IVA masih dikatakan rendah. Hal itu terlihat hanya ada 14 orang siswa yang memiliki kreativitas belajar dilihat dari kriteria sangat baik dan baik sekitar $46,67 \%$.
Pada

pertemuan

II kreativitas belajar siswa telah mengalami sedikit peningkatan, dengan 7 orang yang memperoleh kriteria sangat baik; 9 orang siswa yang memperoleh kriteria baik; 7 orang siswa yang memperoleh kriteria cukup baik; 3 orang siswa yang memperoleh kriteria kurang; dan 4 orang siswa yang memperoleh kriteria kurang sekali. Berdasarkan Tabel 1, diketahui ada 16 siswa yang memiliki persentase kreativitas antara 65\% sampai 100\% dan dapat dikatakan sudah kreatif karena telah memenuhi kriteria penilaian dari indikator kreativitas belajar. Dari rata-rata kelas di atas dapat dikatakan bahwa tingkat kreativitas belajar siswa kelas IVA telah mengalami peningkatan tapi masih dikatakan rendah. Hal itu terlihat hanya ada 16 orang siswa yang memiliki kreativitas belajar dilihat dari kriteria sangat baik dan baik sekitar 53,33\%. Pada siklus II pertemuan I telah mengalami peningkatan yang cukup besar, dengan 10 siswa sudah memperoleh kriteria sangat baik; 12 siswa yang memperoleh kriteria baik; 5 orang siswa yang memperoleh kriteria cukup baik; masih ada 2 orang siswa yang memperoleh kriteria kurang; dan tinggal 1 siswa yang memperoleh kriteria kurang sekali.

Tabel 1. Kreativitas Siswa pada Siklus I dan II

\begin{tabular}{|c|c|c|c|c|c|c|c|c|}
\hline \multirow{2}{*}{$\begin{array}{c}\text { No } \\
\text { Siswa }\end{array}$} & \multicolumn{4}{|c|}{ Siklus I } & \multicolumn{4}{c|}{ Siklus II } \\
\cline { 2 - 9 } & \multicolumn{2}{|c|}{ Per.1 } & \multicolumn{2}{c|}{ Per.2 } & \multicolumn{2}{c|}{ Per.3 } & \multicolumn{2}{c|}{ Per.4 } \\
\hline 1 & 10 & $\begin{array}{c}\text { Kelum } \\
\text { Kreatif }\end{array}$ & 12 & $\begin{array}{c}\text { Belum } \\
\text { Kreatif }\end{array}$ & 17 & Kreatif & 18 & Kreatif \\
\hline 2 & 8 & $\begin{array}{c}\text { Belum } \\
\text { Kreatif }\end{array}$ & 12 & $\begin{array}{c}\text { Belum } \\
\text { Kreatif }\end{array}$ & 15 & Kreatif & 16 & Kreatif \\
\hline 3 & 12 & $\begin{array}{c}\text { Belum } \\
\text { Kreatif }\end{array}$ & 15 & Kreatif & 16 & Kreatif & 18 & Kreatif \\
\hline 4 & 17 & Kreatif & 18 & Kreatif & 19 & Kreatif & 19 & Kreatif \\
\hline
\end{tabular}




\begin{tabular}{|c|c|c|c|c|c|c|c|c|}
\hline \multirow{3}{*}{$\begin{array}{l}\text { No } \\
\text { Siswa }\end{array}$} & \multicolumn{4}{|c|}{ Siklus I } & \multicolumn{4}{|c|}{ Siklus II } \\
\hline & \multicolumn{2}{|c|}{ Per.1 } & \multicolumn{2}{|c|}{ Per.2 } & \multicolumn{2}{|c|}{ Per.3 } & \multicolumn{2}{|c|}{ Per.4 } \\
\hline & Skor & Kriteria & Skor & Kriteria & Skor & Kriteria & Skor & Kriteria \\
\hline 5 & 4 & $\begin{array}{l}\text { Belum } \\
\text { Kreatif }\end{array}$ & 7 & $\begin{array}{l}\text { Belum } \\
\text { Kreatif }\end{array}$ & 9 & $\begin{array}{l}\text { Belum } \\
\text { Kreatif }\end{array}$ & 17 & Kreatif \\
\hline 6 & 17 & Kreatif & 18 & Kreatif & 18 & Kreatif & 19 & Kreatif \\
\hline 7 & 8 & $\begin{array}{l}\text { Belum } \\
\text { Kreatif }\end{array}$ & 11 & $\begin{array}{l}\text { Belum } \\
\text { Kreatif }\end{array}$ & 15 & Kreatif & 16 & Kreatif \\
\hline 8 & 15 & Kreatif & 17 & Kreatif & 18 & Kreatif & 19 & Kreatif \\
\hline 9 & 10 & $\begin{array}{l}\text { Belum } \\
\text { Kreatif }\end{array}$ & 12 & $\begin{array}{l}\text { Belum } \\
\text { Kreatif }\end{array}$ & 15 & Kreatif & 16 & Kreatif \\
\hline 10 & 13 & Kreatif & 14 & Kreatif & 15 & Kreatif & 16 & Kreatif \\
\hline 11 & 13 & Kreatif & 14 & Kreatif & 15 & Kreatif & 16 & Kreatif \\
\hline 12 & 17 & Kreatif & 18 & Kreatif & 18 & Kreatif & 19 & Kreatif \\
\hline 13 & 5 & $\begin{array}{l}\text { Belum } \\
\text { Kreatif }\end{array}$ & 7 & $\begin{array}{l}\text { Belum } \\
\text { Kreatif }\end{array}$ & 8 & $\begin{array}{l}\text { Belum } \\
\text { Kreatif }\end{array}$ & 17 & Kreatif \\
\hline 14 & 3 & $\begin{array}{l}\text { Belum } \\
\text { Kreatif }\end{array}$ & 4 & $\begin{array}{l}\text { Belum } \\
\text { Kreatif }\end{array}$ & 12 & $\begin{array}{l}\text { Belum } \\
\text { Kreatif }\end{array}$ & 17 & Kreatif \\
\hline 15 & 2 & $\begin{array}{l}\text { Belum } \\
\text { Kreatif }\end{array}$ & 3 & $\begin{array}{l}\text { Belum } \\
\text { Kreatif }\end{array}$ & 4 & $\begin{array}{l}\text { Belum } \\
\text { Kreatif }\end{array}$ & 8 & $\begin{array}{l}\text { Belum } \\
\text { Kreatif }\end{array}$ \\
\hline 16 & 3 & $\begin{array}{l}\text { Belum } \\
\text { Kreatif }\end{array}$ & 4 & $\begin{array}{l}\text { Belum } \\
\text { Kreatif }\end{array}$ & 12 & $\begin{array}{l}\text { Belum } \\
\text { Kreatif }\end{array}$ & 17 & Kreatif \\
\hline 17 & 6 & $\begin{array}{l}\text { Belum } \\
\text { Kreatif }\end{array}$ & 10 & $\begin{array}{l}\text { Belum } \\
\text { Kreatif }\end{array}$ & 11 & $\begin{array}{l}\text { Belum } \\
\text { Kreatif }\end{array}$ & 12 & $\begin{array}{l}\text { Belum } \\
\text { Kreatif }\end{array}$ \\
\hline 18 & 13 & Kreatif & 14 & Kreatif & 15 & Kreatif & 16 & Kreatif \\
\hline 19 & 3 & $\begin{array}{l}\text { Belum } \\
\text { Kreatif }\end{array}$ & 4 & $\begin{array}{l}\text { Belum } \\
\text { Kreatif }\end{array}$ & 11 & $\begin{array}{l}\text { Belum } \\
\text { Kreatif }\end{array}$ & 12 & $\begin{array}{l}\text { Belum } \\
\text { Kreatif }\end{array}$ \\
\hline 20 & 4 & $\begin{array}{l}\text { Belum } \\
\text { Kreatif }\end{array}$ & 6 & $\begin{array}{l}\text { Belum } \\
\text { Kreatif }\end{array}$ & 8 & $\begin{array}{l}\text { Belum } \\
\text { Kreatif }\end{array}$ & 12 & $\begin{array}{l}\text { Belum } \\
\text { Kreatif }\end{array}$ \\
\hline 21 & 2 & $\begin{array}{l}\text { Belum } \\
\text { Kreatif }\end{array}$ & 9 & $\begin{array}{l}\text { Belum } \\
\text { Kreatif }\end{array}$ & 13 & Kreatif & 17 & Kreatif \\
\hline 22 & 9 & $\begin{array}{l}\text { Belum } \\
\text { Kreatif }\end{array}$ & 12 & $\begin{array}{l}\text { Belum } \\
\text { Kreatif }\end{array}$ & 15 & Kreatif & 16 & Kreatif \\
\hline 23 & 17 & Kreatif & 18 & Kreatif & 18 & Kreatif & 19 & Kreatif \\
\hline 24 & 12 & $\begin{array}{l}\text { Belum } \\
\text { Kreatif }\end{array}$ & 14 & Kreatif & 15 & Kreatif & 16 & Kreatif \\
\hline 25 & 13 & Kreatif & 14 & Kreatif & 15 & Kreatif & 16 & Kreatif \\
\hline 26 & 17 & Kreatif & 17 & Kreatif & 18 & Kreatif & 19 & Kreatif \\
\hline 27 & 13 & Kreatif & 14 & Kreatif & 14 & Kreatif & 16 & Kreatif \\
\hline 28 & 15 & Kreatif & 16 & Kreatif & 17 & Kreatif & 18 & Kreatif \\
\hline 29 & 13 & Kreatif & 15 & Kreatif & 15 & Kreatif & 16 & Kreatif \\
\hline 30 & 15 & Kreatif & 16 & Kreatif & 17 & Kreatif & 19 & Kreatif \\
\hline
\end{tabular}

Berdasarkan Tabel 1, diketahui ada 22 siswa yang memiliki persentase kreativitas antara $65 \%$ sampai $100 \%$ dan dapat dikatakan sudah kreatif karena telah memenuhi kriteria penilaian dari indikator kreativitas belajar.
Dari rata - rata kelas di atas dapat dikatakan bahwa tingkat kreativitas belajar siswa kelas IVA telah banyak meningkat dan dapat dikatakan sedang. Hal itu terlihat dari sudah ada 22 orang siswa yang memiliki kreativitas belajar dilihat 
dari kriteria sangat baik dan baik sekitar $73,33 \%$. Pada pertemuan terakhir, IVA telah meningkat dan dapat dilihat pada: Sudah terdapat 12 orang orang yang memperoleh memperoleh kriteria sangat baik. Sudah terdapat 14 orang siswa yang memperoleh kriteria baik. Sudah 3 orang siswa yang memperoleh kriteria cukup baik. Hanya 1 orang siswa yang memperoleh kriteria kurang. Berdasarkan hasil yang diperoleh diketahui ada 26 siswa yang memiliki persentase kreativitas antara $65 \%$ sampai $100 \%$ dan dapat dikatakan sudah kreatif karena telah memenuhi kriteria penilaian dari indikator kreativitas belajar. Dari rata - rata kelas di atas dapat dikatakan bahwa tingkat kreativitas belajar siswa kelas IVA telah mengalami peningkatan dan sudah tergolong kreativitas belajar yang tinggi. Hal itu terlihat sudah ada 26 orang siswa yang emiliki kreativitas belajar dilihat dari kriteria sangat baik dan baik sekitar 86,67\%.

\section{SIMPULAN DAN SARAN Simpulan}

Peningkatan kreativitas

belajar siswa yang mana pada

siklus I pertemuan pertama yaitu sebanyak 13 siswa yang sudah masuk dalam kategori kreatif namun persentase siswa kreatif sebesar $46,67 \%$ secara keseluruhan tergolong kriteria kreativitas belajar siswa yang masih rendah. Sedangkan pada siklus I pertemuan kedua kreativitas belajar siswa mengalami sedikit peningkatan. Sebanyak 16 orang siswa telah dapat dikatakan kreatif. Persentasenya sebesar $53,33 \%$ siswa secara kseluruhan kelas yang sudah kreatif. Namun masih dikategorikan kreativitas belajar siswa secara keseluruhan kelas masih rendah walaupun mengalami peningkatan sebesar 6,67\%. Pada siklus II pertemuan kedua terjadi peningkatan yang besar terhadap kreativitas belajar siswa. Sebanyak 22 orang siswa telah dapat dikatakan kreatif. Persentasenya secara keseluruhan kelas sudah mencapai $73,33 \%$ dan sudah masuk kedalam kategori kreativitas belajar yang tinggi. Pertemuan ketiga ini mengalami peningkatan sebesar $20 \%$ dari pertemuan sebelummnya. Pada pertemuan keempat sudah ada 26 siswa dari total keseluruhan kelas yang telah dapat dikatakan kreatif. Persentasenya secara keseluruhan kelas adalah sebesar $86,67 \%$ dan sudah dapat dikatakan kreativitas belajar siswa secara keseluruhan kelas sudah masuk ke dalam kategori kreativitas belajar yang tinggi. Saran

Berdasarkan hasil penelitian yang diperoleh, peneliti menyampaikan saran : 1) kepada guru kelas supaya lebih kreatif dalam merangsang siswa untuk bertanya dan menyampaikan pendapatnya, 2) agar guru kelas dapat menerapkan pembelajaran kontekstual dalam pembelajaran di kelas,

\section{DAFTAR PUSTAKA}

Aly, Abdullah. 2008. Ilmu Alamiah Dasar. Jakarta : Bumi Aksara.

Arikunto, Suharsimi. 2009. Dasar dasaar Evaluasi Pendidikan. Jakarta : Bumi Aksara.

Asy'ari, Muslichach. 2006. Penerapan Pendekatan Sains - 
Teknologi Masyarakat dalam Pembelajaran Sains di Sekolah Dasar. Jakarta : Departemen Pendidikan Nasional Direktorat Jendral Pendidikan Tinggi Direktorat Ketenagaan. Dewi, Rosmala. 2010.

Profesionalisasi Guru melalui Penelitian Tindakan Kelas. Medan : Pasca Sarjana Unimed.

Haryanto. 2007. Sains Untuk Sekolah Dasar Kelas IV Berdasarkan KTSP 2006. Jakarta : Erlangga.

Johnson, Elaine. 2007. Contextual Teaching And Learning. Bandung: MLC.

Kunandar. 2007. Guru Profesional - Implementasi KTSP dan Sukses dalam Sertifikasi Guru. Jakarta : Raja Grafindo Persada.

Muhith, Saekhan. 2007. Pembelajaran Kontekstual. Semarang : RaSAIL Media Group.

Munandar, Utami. 2009. Pengembangan Kreativitas Anak Berbakat. Jakarta : Rineka Cipta.

Muslich, Masnur. 2011. KTSP Pembelajaran Berbasis Kompetensi dan Kontekstual. Jakarta : Bumi Aksara.

Nasution, S. 2008. Berbagai Pendekatan dalam Proses Belajar dan Mengajar. Jakarta : Bumi Aksara.

Sanjaya, Wina. 2010. Strategi Pembelajaran Berorientasi Standar Proses Pendidikan. Jakarta : Kencana.

Slameto. 2010. Belajar dan Faktorfaktor yang Mempengaruhinya. Jakarta : Rineka Cipta.
Sukardi. 2009. Metodologi Penelitian Pendidikan. Jakarta : Bumi Aksara.

Sutikno, Sobry. 2009. Belajar dan Pembelajaran. Bandung : Prospect Bandung.

Syah, Darwyan dkk. 2009. Pengantar Statistik Pendidikan. Jakarta : Gaung Persada Press Jakarta.

http://tpardede. wikispaces.com/file/v iew/ipa_unit_1.pdf/.

Didownload pada 12 Januari 2012.

http://ansah89blogsport.com/2009/02 /kelemahan-dan-kelebihan-ctlpakem.html didownload pada 9 Januari 2012. 